\title{
sciendo
}

\section{ENTREPRENEURIAL INTENTION IN THE VISEGRAD COUNTRIES}

\author{
Andrea S. Gubik ${ }^{1}$, Szilveszter Farkas ${ }^{2}$
}

\begin{abstract}
In order to boost students' entrepreneurial activities, it is essential to identify the factors that form entrepreneurial intentions and to investigate how the development of these factors can be influenced. This paper attempts to explore the main drivers of entrepreneurial intentions and to examine national differences in students' entrepreneurship by using the database of the GUESSS research project related to the Visegrad countries, namely Poland, the Czech Republic, Slovakia and Hungary. This paper adopts Ajzen's Theory of Planned Behaviour, according to which attitudes, subjective norms and perceived behavioural control influence entrepreneurial intentions.

The results of this research confirm the significant role that attitudes, social norms and perceived behavioural control play in shaping students' entrepreneurial intentions. Differences can be experienced not only in the level of intentions, but also in the strength of each factor across Visegrad countries, which suggests that there is a need for solutions tailored the students' needs in different Visegrad countries. Neither the age nor the gender that are frequently investigated in the literature can significantly increase the explanatory power of the Ajzen's model. Their effect may be perceived in different attitudes and different behavioural control.
\end{abstract}

\section{Keywords}

Entrepreneurship, Entrepreneurial Intention, Visegrad Countries, Higher Education, GUESSS Research

\section{Introduction}

Entrepreneurship is of determining importance in increasing the economic performance of national economies and in boosting employment (Carree and Thurik, 2010; Hope, 2016). Also, the financial crisis of 2008 substantially influenced the labour market and the issue of employment has become increasingly important since then. Their social role in promoting creativity, enhancing self-realisation and reaching the set social objectives is also crucial.

\footnotetext{
${ }^{1}$ University of Miskolc, H-3515 Miskolc-Egyetemváros, Hungary. E-mail: getgubik@uni-miskolc.hu.

${ }^{2}$ Budapest Business School, Buzogány u. 10-12. H-1149 Budapest, Hungary. E-mail: farkas.szilveszter@unibge.hu.
} 
In addition, recent advancements in digitalisation have an impact on jobs and employment (job losses, rises in inequality, changes in employment patterns) and create new challenges for labor market participants. Therefore, it is paramount to determine how to encourage the formation of an increasing number of enterprises and how to enable enterprises to grow rapidly and to create considerable value. Companies formed by young people, especially by professionals, adopt cutting-edge technologies, add values and have a growth potential. This objective of the paper investigates the most important driving forces of students' start-up intentions and attempts to establish whether there are significant differences and similarities in intentions among students in Visegrad countries by using Ajzen's Theory of Planned Behaviour and the database of the GUESSS (Global University Entrepreneurial Spirit Students' Survey) project survey of 2016.

\section{Literature review}

Within the promotion of entrepreneurship across Europe, special attention is paid to young people who are considering starting their own businesses. The findings of research studies into entrepreneurship reveal that students with higher education degrees establish their enterprises in higher value-added sectors (for instance, in high-tech industries), invest a higher amount of initial capital (Richert and Schiller, 1994, cited by Lüthje and Franke, 2002) are more growth oriented (Autio, 2005; Schrör 2006) and are more successful in maintaining the enterprise for longer period of time (Hunady et al. 2018) than other young people. It is therefore of utmost importance for economic policies to foster entrepreneurial intentions and activities of students in tertiary education.

The Entrepreneurship 2020 Action Plan (EC, 2013), the Youth Entrepreneurship in Europe: Values, Attitudes, Policies (Eurofound, 2015) and Erasmus for Young Entrepreneurs (EYE (2015) deal with Europe's entrepreneurial potential and come to a shared conclusion that students in tertiary education should be offered complex support in becoming informed about best entrepreneurial practices; entrepreneurship education should be modernized and improved; and various financial support schemes should be made available for young entrepreneurs. The United Nations defines a youth as a person between the ages of 15 and 24; Eurostat includes people aged between 15 and 29 years in this group and the Global Entrepreneurship Monitor (GEM) considers youth to be people between the ages of 18 and 34 years. Although university students and students studying in other higher educational institutions make up only a special subset of the youth population, this target audience plays a determining role in entrepreneurship (in terms of higher added value, more growth-orientated start-ups, etc.). Therefore, this paper focuses on higher education students and the age group of young people enrolled in higher educational institutions. The academic literature frequently investigates issues related to how entrepreneurial activities can be influenced and fostered and what factors affect and contribute to the development of start-up visions. Ensuring the financial resources required to start a business seems to be a simple solution to the problem of how to enhance entrepreneurship. However, this does not always trigger a massive wave of start-ups. The authors of this paper believe that the provision of the resources (financial and material conditions) is necessary, 
but not sufficient to enhance and boost entrepreneurship. The same seems to be true with regard to the formal institutional environment, namely to tax systems and administrative burdens.

Perhaps the role of education in entrepreneurship is the most frequently investigated topic in the entrepreneurial literature. Education significantly affects intentions towards entrepreneurship (Nowiński et al. 2017, Maresch et al. 2016). Students gain the knowledge necessary to run a business, and thus, learn about their entrepreneurial aptitude (von Graevenitz et al. 2010), improve their self-efficacy (Egerová et al. 2017) and increase their chances for a successful business (Kolstad and Wiig, 2015) However, there are several ongoing debates on how education can promote entrepreneurship. Conventional educational methods develop entrepreneurial traits and attributes to a lesser degree (EC, 2008). There is a great need for innovative solutions in education that enhance the training of students in the skills and knowledge necessary to start an enterprise and run it successfully. In addition, skills crucial to running a successful enterprise are more likely to be acquired in existing businesses (Szirmai and Csapó, 2006). However, empirical studies reveal that formal education still contributes significantly to the development of entrepreneurial aspirations (Gubik 2013; Szerb and Lukovszki, 2013). Entrepreneurship education focusing on increasing creativity, self-efficacy, systematic thinking, awareness of opportunities and learning to learn, fosters not only entrepreneurship but increases the overall employability of students (Ling and Venesaar, 2015).

There are studies that address the presence or the lack of entrepreneurial characteristics. According to Meager et al. (2003) the willingness to take risks and the desire to become independent seem to be especially crucial entrepreneurial characteristics. Other studies point out that apart from or instead of characteristics (which either can hardly be shaped or cannot be shaped at all), entrepreneurial thinking and entrepreneurial mindset should be considered to be major determinants of success, since they show what behaviour and attitude can be expected from individuals during an entrepreneurial process (Gauthier et al., 2018).

Several studies deal with the role of social environment in the process of entrepreneurship. Autio and Wennberg (2010) suggest that individuals' community norms and attitudes can have more influence on young people's entrepreneurial behaviour than their own personal attitudes and perceived self-efficacy.

Some other studies believe that national cultures also have an impact on entrepreneurship. One group of studies investigated the influence of national cultures on individuals' characteristics (Thomas and Mueller, 2000; Thurik and Dejardin, 2012). The other group associated cultural dimensions with aggregated entrepreneurial statistics (Shane et al. 1991; Zhao et al. 2012).

In the extensive literature on entrepreneurship the complex models that attempt to integrate the above-mentioned impacts (individual, society and institutional system) into one complex system may provide a roadmap to understanding entrepreneurship. Such models are, for example, Social Cognitive Theory (Bandura, 1977, 1989), the Entrepreneurial Event (Shapero and Sokol, 1982), and the Theory of Planned Behaviour (Ajzen, 1991), which this paper is based on. All three models attribute a prominent role to persons' scales 
of value, attitudes, and impressions, consider signals coming from the environment and the society and highlight their effects on each other.

\section{Visegrad countries}

There are a variety of factors that connect Visegrad Countries (Czech Republic, Hungary, Poland and Slovakia) and have a considerable impact on their economic and social development. One of the factors is socialist economic and social regimes developed after World War II when private ownership was eliminated. Large and medium-sized enterprises were completely nationalised and operated in a planned-directed economic system. Smallsized enterprises remained to operate only in very few service sectors. Although there were several smaller or larger reforms until the changes in the regime of 1989-1990 in Visegrad countries in order to improve the adaptability of their economies, these reforms failed to spectacularly enhance private enterprise growth.

Fundamental changes in enterprise ownership structures were observed only after the political and economic reforms when compensation to former enterprise owners, privatisation of state-owned companies, and the transformation of economic institutional system was started in order to enhance the transformation from central planning to a market economy. The process would not have functioned without entrepreneurs and enterprises. Entrepreneurs in Hungary became managers and talented professionals (engineers, economists, etc.) in privatised 'socialist' companies who tried themselves as entrepreneurs in hidden enterprises (economic working communities and intra-company economic working partnerships). The success of reforms in Central and Eastern European countries resulted in their accession to the EU. Political and economic institutions meeting the key criteria for EU membership were established and could permanently ensure democratic and market economy development in the Visegrad countries. Results of several research studies reveal that economic and social processes of 1990s determined the entrepreneurship development and its level of development (see for example Szerb and Trunbull, 2015).

Although the historical roots are quite similar in Visegrad countries, there are significant country-specific characteristics, for instance, their official languages and legislations. As far as entrepreneurship is concerned, the Global Entrepreneurship Index (GEI) also shows significant differences among Visegrad Countries. This index is calculated on the basis of the Global Entrepreneurship Monitor (GEM) factors (like individual abilities, motivations and attitudes related to enterprises) and the role of institutional and entrepreneurial ecosystems is also taken into account (Szerb and Trunbull, 2015). The GEI results show that Visegrad countries rank in the first-third: Poland is 30th, Slovakia is 36th, Czech Republic is 38th and Hungary is 50th among examined countries in 2018. The Youth on the Move Report reveals differences in entrepreneurial intentions among these countries' youth (Eurobarometer, 2011). Also, the GUESSS data support and other researches reinforce these differences. Beauchamp and Skala (2017) examining the start-up activity of the Visegrad Countries noted that the shared start-up ecosystem is missing because of several key barriers. 


\section{Theoretical and methodological framework of the research}

The aim of the Theory of Planned Behaviour Model of Ajzen is to describe human behaviour with three variables. According to the model, human behaviour is formed by three kinds of considerations: beliefs about the likely outcomes of the behaviour and the evaluations of these outcomes (behavioural beliefs), beliefs about the normative expectations of others and motivation to comply with these expectations (normative beliefs), and beliefs about the presence of factors that may facilitate or impede performance of the behaviour and the perceived power of these factors (control beliefs) (Ajzen, 2006b). These beliefs form the following elements of the model: attitudes, subjective norms and perceived behavioural control. The model can help to understand any type of human behaviour, so it may also be suitable to predict entrepreneurial intentions.

There are some comparative studies where the model is compared with other models and was found suitable for explaining entrepreneurial intentions and activities (see, for example, Krueger et al., 2000).

Since the GUESSS's research concept relies on Ajzen's Theory of Planned Behaviour (1991), this paper is also using this model for identifying the driving forces of students' start-up intentions and for establishing differences in intentions among students in Visegrad Countries. According to this theory, attitude, subjective norms and the degree of behavioural control together influence the individual's willingness to become an entrepreneur, which can eventually manifest in the individual's actions. Figure 1 illustrates Ajzen's Theory of Planned Behaviour.

Figure 1: Theory of planned behavior

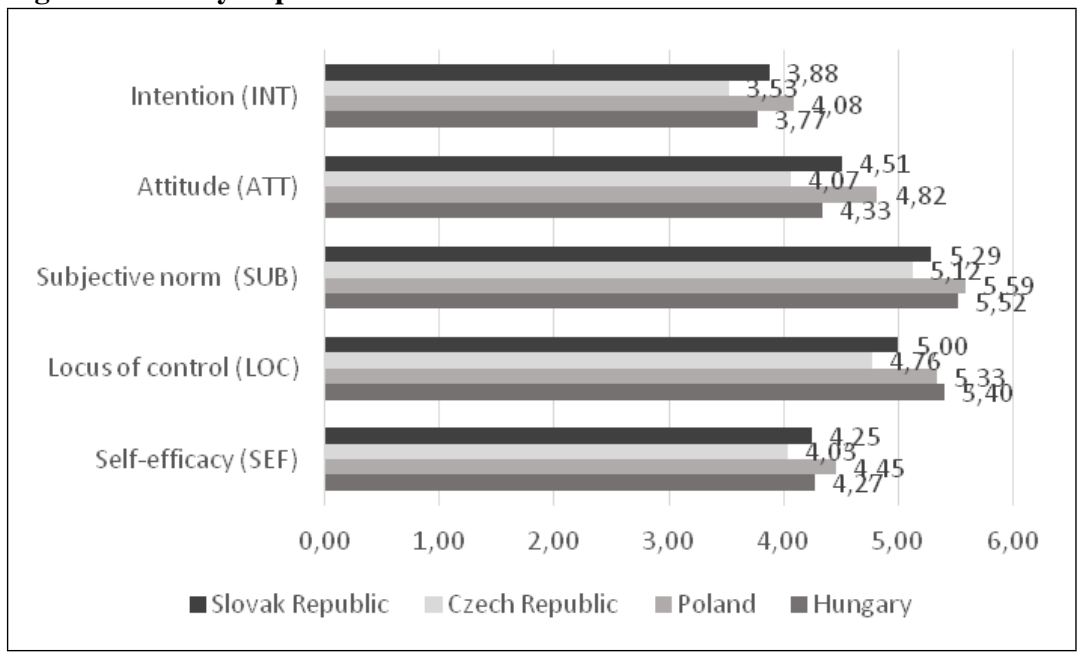

Source: Ajzen $2006 a$

One of the main ideas of Ajzen's theory is that there is a difference between intentions and behaviours. If there is a serious entrepreneurial intention, it does not necessarily mean that entrepreneurial activity will be pursued and an enterprise will be set up. Intentions 
depend on the attitudes towards behaviour, subjective norms and the perceived behavioural control. Actual pursued activities cannot be expected without serious intentions. Objective factors such as available financial resources and open opportunities that are required for carrying out intentions also influence business activities. These factors are termed actual control in the revised Ajzen's Theory model (Ajzen, 2006a). According to this model, there is a direct positive relationship between the entrepreneurial attitude and the willingness to start up a business. The more favourable a person's attitude toward entrepreneurship is, the stronger the intention to run an enterprise is. A supporting social environment is also nourishing for entrepreneurial intentions (social norm). Thus, the more positively the individuals' environment reacts to their entrepreneurial intentions, the more likely they will show willingness to start up their own businesses.

The third factor, the perceived control over events, also has a direct influence on the individuals' intention to start up an enterprise and can also have a significant effect on their behaviour. The impact of the perceived behavioural control on intentions and actions is twofold. Firstly, the more individuals feel that they are in control of their surroundings, the more likely they are to be in favour of starting up their own ventures (locus of control). Secondly, self-efficacy also has a positive effect on entrepreneurial spirits. The more an individual feels that he/she has acquired the appropriate skills and knowledge to start an enterprise, the more likely he/she is to think that his/her own business can be launched. Besides the same intentions, different levels of perceived behavioural control will cause different efforts and thus, it will influence directly the success of the behaviour (Ajzen, 2006b).

The factors listed above are correlated with each other, and there is an additional significant relationship between the two elements of perceived behavioural control, namely between the locus of control and the self-efficacy. The two factors can support each other but a negative relationship can also be possible. A person who has the necessary knowledge and experience can feel that things are getting out of his/her hand.

Finally, these factors are highly influenced by the individual's personality, family background, macro- or microenvironment and the higher educational institution he attended. The importance of higher education lies in the knowledge and skill transfer needed for starting and running a successful business and in the ability to enhance entrepreneurial intentions and to ease negative factors (unfavourable financial situation, disadvantaged family background, etc.) Apart from testing the factors in the Ajzen model, the questionnaire of this study also focuses on these variables.

As for the methodology used in the entrepreneurial literature, multinomial regression analysis is generally used to investigate start-up intentions; see, for example the work of Zellweger et al. (2011) and Szerb and Márkus (2007). The advantage of this method is that it can be used in cases where the dependent variable is categorical (the independent variables can be either dichotomous or continuous). This method can reliably be used to measure the combined explanatory power of independent variables and to check the partial significant effect of each variable involved in the examination.

Gubik (2013) tested the Ajzen model on a sample of Hungarian students by using the multinomial logistic regression. The test results show that both the perceived behavioural 
control and attitudes channel entrepreneurial intentions in a positive direction. The test failed to support the role of the subjective norm in entrepreneurship. The extension of the model (to gender, age, field of study, the effect of the university environment) improved the explanatory power of the model.

Szerb and Lukovszki (2013) also applied multinomial logistic regression in their studies but they tested their own model, which contained only the variables of the Ajzen model that measured self-efficacy. They termed these variables Awareness, Innovative Capacity and Risk Management. Both studies highlight the driving force of the family entrepreneurial background and the role of education in entrepreneurship. Gubik (2013) investigated the role of education in students' entrepreneurship intentions based on the number of attended entrepreneurship courses and involved resources, while Szerb and Lukovszki used the form of dichotomous variable (whether students participated in entrepreneurship education or not).

There are also studies based on structural equation modelling (SEM) (Kolvereid, 1996; Plant and Ren, 2010; Gubik et al. 2018). Gubik et al., using the GUESSS 2011 database, justified the central role of attitudes in entrepreneurial intentions and activities and the attitude shaping effect of subjective norms. The GUESSS database of 2011 also allowed the analysis of the relationship between intentions and activities.

The current study applies the multiple linear regression model, which makes it possible to express dependent variables as a linear function of several independent variables. (Ketskeméty and Izsó, 2005).

\section{Hypotheses}

There is a consensus in the entrepreneurship literature on the role of attitudes, namely that a positive attitude towards an entrepreneurial career channels entrepreneurship in a positive direction (Wach and Wojciechowski, 2016, Gubik, 2013, Nishimura and Tristán 2011, Liñán and Chen 2009, Autio et al. 2001, Krueger et al. 2000). In addition, several empirical tests of previous research studies revealed that the relationship between two elements in the model, namely between attitude and entrepreneurial intentions, is the strongest (Liñán and Chen, 2009).

\section{H1: Attitudes towards entrepreneurship affect start-up intentions in a positive direction.}

Earlier studies failed to provide sufficient evidence to support the significant impact of subjective norms on entrepreneurship. Engle et al. (2010) conducted research into different variables of the Ajzen model in twelve countries and found that only the subjective norm variable was proved to be an important predictor in the investigated countries. Ozaralli and Rivenburgh (2016), and Kautonen et al. (2015) found a similar relationship between entrepreneurial intentions and the subjective norm.

However, other studies (Autio et al. 2001; Krueger et al. 2000; Nishimura and Tristán 2011; Liñán and Chen, 2009; Gubik, 2013; Wach and Wojciechowski, 2016) failed to identify a relationship between entrepreneurial intentions and subjective norms. A great number of studies reported the relationship between the model's variables. Nishimura and Tristán (2011) highlighted that although there is a significant linear correlation coefficient, 
the effect of the subjective norm on the development of the intention to become an entrepreneur is non-significant in the logistic regression model. This may indicate that subjective norms do not necessarily have a direct effect on forming intentions. These norms influence entrepreneurial ideas through targeting start-up attitudes and shaping perceived behavioural control. This assumption is supported by the results of correlation coefficients among the subjective norm and attitudes and perceived behavioural control. Autio et al. (2001) found a significantly positive correlation between perceived behavioural control and the subjective norm. Liñán and Chen (2009) proved the impact of subjective norms on attitudes and the perceived behavioural control in Spain and Taiwan by applying structural equation modelling (their analyses are based on the GEM database).

On the basis of the contradictory research results regarding the relationship between subjective norm and intention, this study assumes that the subjective norm indirectly influences the intention of students to start a business. The following hypotheses are accordingly the following:

H2a: The subjective norm affects attitudes in a positive direction.

H2b: The subjective norm affects perceived behaviour control in a positive direction.

A number of studies supported the positive effect of perceived behavioural control on the intention to form an enterprise (Wach and Wojciechowski 2016, Autio et al. 2001; Krueger et al. 2000; Nishimura and Tristán 2011; Liñán and Chen, 2009; Kautonen et al. 2015). Research studies based on the Hungarian database also provide similar results (Gubik, 2013, 2016).

Taking into account the theoretical background and earlier tests of the model, the following hypothesis is as follows:

H3: The perceived behavioural control significantly affects start-up intentions in a positive direction.

When analysing entrepreneurship, researchers often consider the Visegrad countries to be a homogenous group (Holienka et al. 2017, Holienka et al. 2016). However, there are studies that emphasize differences between Visegrad countries (Nowiński et al. 2017, Beauchamp and Skala, 2017, Eurobarometer 2011). A start-up ecosystem research (Kolstad and Wiig, 2015) highlighted the lack of a unified ecosystem in these countries. Although identical factors determined the economic and social development of Visegrad Four in the second half of the 20th century and the reforms in 1989-1990 resulted in establishing more or less similar economic and social institutional systems in order to promote entrepreneurial activities (Szerb and Trunbull 2015), the economically active population's entrepreneurship and entrepreneurial activities, including young people's and higher educational students', may differ.

H4a: There are significant differences in students' start-up intentions across Visegrad Four.

H4b: The effects of the factors differ across Visegrad countries. 


\section{Database and methodology}

The GUESSS (Global University Entrepreneurial Spirit Students' Survey) investigates students' entrepreneurial intentions and activities. The main aim of the research is to identify students' individual motivations, personal background characteristics (family backgrounds) and institutional factors (higher educational environment) that significantly affect the process of becoming an entrepreneur.

Data collection is carried out every two years. The first survey was conducted in 2003 with the participation of only two countries. The database of 2016 survey is made up of 122,509 valid student responses from 50 countries, including 15,971 student responses from the four Visegrad countries: 5,182 responses from Hungary, 6,388 responses from Poland, 1,135 Czech responses and 3,266 Slovak responses.

In the Visegrad database $63.7 \%$ of the respondents were female. As for the age of respondents, $75.3 \%$ were under the age of $25 ; 17.1 \%$ were between $25-30$ years and the remaining respondents were older than 30. The highest proportion of respondents (34.6\%) studied economics (including business sciences) and law, 22.4\% of them majored in technical studies, $9.8 \%$ studied human medicine and health sciences, $7.4 \%$ of them studied social sciences, $5.5 \%$ were students of humanities and $0.7 \%$ majored in art sciences. The remaining students chose the 'other' category. In the sample $68.8 \%$ of respondents were bachelor students (undergraduate), $24.3 \%$ were studying towards a master's degree (graduate) and $6.9 \%$ indicated other study programs ( $\mathrm{PhD}$, etc.).

Table 1 shows the main descriptive statistics of the Visegrad Four respondents by country.

\section{Variables of the examination}

On the basis of the survey of 2016, the factors of Ajzen's model as well as the most important factors influencing them can be analysed. When operationalizing these concepts, this study heavily relied on the related literature. The questionnaire in this study also contains questions applied by conventional research methods.

\section{Entrepreneurial intention}

Please indicate your level of agreement with the following statements: I am ready to do anything to be an entrepreneur! My professional goal is to become an entrepreneur; I will make every effort to start and run my own business; I am determined to create a business in the future; I have a very seriously thought of starting a business; I have a strong intention to start a business someday. (1-7 Likert scale)

\section{Attitudes}

Please indicate your level of agreement with the following statements: Being an entrepreneur implies more advantages than disadvantages to me; A career as entrepreneur is attractive for me; If I had the opportunity and resources, I would become an entrepreneur; Being an entrepreneur would be very satisfying for me; Among various options, I would rather become an entrepreneur. (1-7 Likert scale) 


\section{Social norms}

If you were to pursue a career as an entrepreneur, how would people in your environment react? Your close family/your friends/your fellow students. (1-7 Likert scale)

\section{Perceived behavioural control}

Locus of control

Please indicate your level of agreement with the following statements: I am usually able to protect my personal interests; When I make plans, I am almost certain to make them work; I can pretty much determine what will happen in my life. (1-7 Likert scale)

\section{Self-efficacy}

Please indicate your level of competence in performing the following tasks: Identifying new business opportunities; Creating new products and services; Managing innovation within a business; Being a leader and a communicator; Building up a professional network; Commercializing a new idea or development; Successfully managing a business.

(1-7 Likert scale)

\section{Further variables}

What is your year of birth?

Your gender? Male/Female

Please indicate the extent to which you agree with the following statements about the university environment: The atmosphere at my university inspires me to develop ideas for new businesses; There is a favourable climate for becoming an entrepreneur at my university; At my university, students are encouraged to engage in entrepreneurial activities. (1-7 Likert scale)

Please indicate the extent to which you agree with the following statements about your studies: The courses and offerings I attended ... increased my understanding of the attitudes, values and motivations of entrepreneurs; ... increased my understanding of the actions someone has to take to start a business; . . enhanced my practical management skills in order to start a business; . . . enhanced my ability to develop networks; $\ldots$. enhanced my ability to identify an opportunity. (1-7 Likert scale)

Are your parents self-employed? No/Yes, my father is/Yes, my mother is/Yes, both are. Are your parents majority owners of a business? No/Yes, my father is/Yes, my mother is/Yes, both. 
Table 1: Descriptive statistics of the Visegrad Four respondents (2016)

\begin{tabular}{|c|c|c|c|c|}
\hline Country & Study level, sex & $\%$ & Area of studies & $\%$ \\
\hline \multirow{8}{*}{$\begin{array}{l}\text { Hungary } \\
5,182 \\
\text { respondents }\end{array}$} & Undergraduate & 73.1 & Arts / Humanities & 3.8 \\
\hline & Graduate & 14.4 & Engineering & 28.0 \\
\hline & Other & 12.5 & Human medicine / health sciences & 15.5 \\
\hline & Female & 58.6 & Law \& economics & 33.2 \\
\hline & Male (\%) & 41.4 & Mathematics and natural sciences & 4.6 \\
\hline & & & Art sciences & 0.5 \\
\hline & & & Social sciences & 4.7 \\
\hline & & & Other & 9.7 \\
\hline \multirow{8}{*}{$\begin{array}{l}\text { Poland } \\
6,388 \\
\text { respondents }\end{array}$} & Undergraduate & 73.9 & Arts / Humanities & 3.8 \\
\hline & Graduate & 22.9 & Engineering & 24.5 \\
\hline & Other & 3.2 & Human medicine / health sciences & 7.2 \\
\hline & Female & 64.4 & Law \& economics & 31.7 \\
\hline & Male & 35.6 & Mathematics and natural sciences & 4.9 \\
\hline & & & Art sciences & 0.1 \\
\hline & & & Social sciences & 7.7 \\
\hline & & & Other & 20.0 \\
\hline \multirow{8}{*}{$\begin{array}{l}\text { The Czech Republic } \\
1,135 \\
\text { respondents }\end{array}$} & Undergraduate & 57.2 & Arts / Humanities & 5.1 \\
\hline & Graduate & 39.7 & Engineering & 20.0 \\
\hline & Other & 3.1 & Human medicine / health sciences & 4.1 \\
\hline & Female & 62.2 & Law \& economics & 46.6 \\
\hline & Male & 37.8 & Mathematics and natural sciences & 4.8 \\
\hline & & & Art sciences & 3.5 \\
\hline & & & Social sciences & 2.5 \\
\hline & & & Other & 13.5 \\
\hline \multirow{8}{*}{$\begin{array}{l}\text { The Slovak Republic } \\
3,266 \\
\text { respondents }\end{array}$} & Undergraduate & 56.3 & Arts / Humanities & 11.6 \\
\hline & Graduate & 37.3 & Engineering & 10.4 \\
\hline & Other & 6.4 & Human medicine / health sciences & 7.8 \\
\hline & Female & 71.0 & Law \& economics & 38.2 \\
\hline & Male & 29.0 & Mathematics and natural sciences & 9.1 \\
\hline & & & Art sciences & 0.9 \\
\hline & & & Social sciences & 12.9 \\
\hline & & & Other & 9.1 \\
\hline
\end{tabular}

Source: own calculations based on GUESSS 2016 database

Arts / Humanities (linguistics, cultural studies, religion, philosophy, history); Social sciences (psychology, politics, educational science); Engineering (including computer sciences and architecture); Art sciences (art, design, dramatics, music) 


\section{Results}

When the responses of the Visegrad Four students were analysed, the arithmetic mean score for each item of some descriptive variables of the Ajzen model were calculated. Instead of the mean values, a factor analysis can also be conducted, which provides very similar results, however, the easy interpretation of the original scale ranging from 1 to 7 would be not be possible.

This paper reveals that there is a weak significant relationship between start-up intentions of university/college students and the country variables. The same is true regarding all model components, attitudes, perceived behavioural control (locus of control and selfefficacy) and the subjective norm (the Kruskal-Wallis test and the posthoc analysis in Kruskal-Wallis test confirmed the existence of differences between the countries).

Figure 2: Differences of the Ajzen model's elements by Visegrad countries (own calculation)

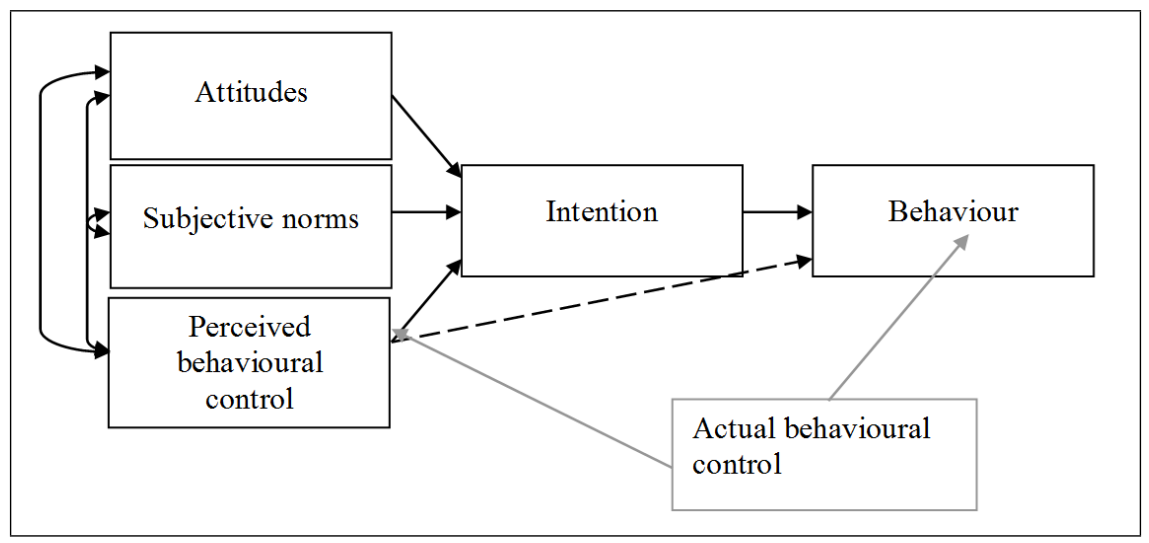

First, by applying the multiple linear regression model, this paper aims to examine whether the factors of the Ajzen model, namely attitudes, perceived behavioural control (locus of control, self-efficacy) and the subjective norm, can be identified in entrepreneurial intentions in Visegrad Four. The conditions for the multiple linear regression model must be satisfied to enable us to interpret the parameters (Szilágyi and Varga, 2011). The normality of errors was checked graphically. Homoscedasticity scatter plot was used to establish that the residuals are homoscedastic.

Multicollinearity was assessed with the Variance Inflation Factor (VIF). The available literature fails to provide a clear threshold for indicating the adverse affects of multicollinearity (Kovács 2008). VIF values of 5 or greater than 5 indicate that multicollinearity is strong. Since the VIF values in the Visegrad samples are far below this threshold, there is no multicollinearity between the examined factors.

Both the $R$ Square statistic (Adjusted $R$ Square $=0.763$ ) and the $F$-test show that the explanatory power of the model is high and amounts to $76.3 \%$, which means that the independent variables in the model can explain $76.3 \%$ of the dependent variables. All factors in the model are significant (Table 2 presents the significance levels of the $t$-tests). 
Table 2: Coefficients of the model

\begin{tabular}{|c|c|c|c|c|c|c|c|c|c|c|}
\hline \multirow[t]{2}{*}{ Model } & \multicolumn{2}{|c|}{$\begin{array}{c}\text { Unstandardized } \\
\text { Coefficients }\end{array}$} & \multirow{2}{*}{$\begin{array}{c}\begin{array}{c}\text { Standardized } \\
\text { Coefficients }\end{array} \\
\text { Beta }\end{array}$} & \multirow[t]{2}{*}{$t$} & \multirow[t]{2}{*}{ Sig. } & \multicolumn{3}{|c|}{ Correlations } & \multicolumn{2}{|c|}{$\begin{array}{c}\text { Collinearity } \\
\text { Statistics }\end{array}$} \\
\hline & B & $\begin{array}{l}\text { Std. } \\
\text { Error }\end{array}$ & & & & $\begin{array}{l}\text { Zero- } \\
\text { order }\end{array}$ & Partial & Part & Tolerance & VIF \\
\hline (Constant) & -.984 & .018 & & -55.911 & .000 & & & & & \\
\hline ATT & .888 & .002 & .771 & 375.787 & .000 & .866 & .763 & .575 & .556 & 1.799 \\
\hline SUB & .008 & .003 & .005 & 2.693 & .007 & .436 & .008 & .004 & .727 & 1.375 \\
\hline LOC & -.025 & .003 & -.014 & -7.981 & .000 & .359 & -.025 & -.012 & .720 & 1.390 \\
\hline SEF & .228 & .003 & .156 & 72.867 & .000 & .634 & .223 & .111 & .510 & 1.962 \\
\hline
\end{tabular}

Source: own calculation based on GUESSS 2016

Despite low multicollinearity and significant correlations, the inclusion of two factors in the model, namely the subjective norm and locus of control, needs to be reconsidered because the partial correlation coefficient of these two variables is low. When the variables are omitted, the explanatory power of the model does not change significantly, which also indicates that these variables should not be included in the model. The large sample size in this survey allows the $t$-test such a large number of degrees of freedom that any small values are considered as significant differences.

In the next step, the linear regression analysis was repeated, but the sample was broken down into four countries to detect any differences among Visegrad Four and to have smaller sample sizes for further analyses.

Table 3 presents the coefficients of determination of the model and Table 4 allows analysing the partial effect of specific variables.

Table 3: Model Summary

\begin{tabular}{|l|c|c|c|c|}
\hline Visegrad Countries & R & R Square & Adjusted R Square & Std. Error of the Estimate \\
\hline Hungary (HUN) & .874 & .765 & .764 & .92160 \\
\hline Poland (POL) & .818 & .670 & .669 & .99318 \\
\hline Czech Republic (CZE) & .872 & .761 & .760 & .94540 \\
\hline Slovak Republic (SVK) & .875 & .766 & .766 & .89711 \\
\hline
\end{tabular}

Source: own calculation based on GUESSS 2016 
Table 4: Coefficients of the Visegrad Countries

\begin{tabular}{|c|c|c|c|c|c|c|c|c|c|c|c|}
\hline \multirow[t]{2}{*}{ V4 } & \multirow[t]{2}{*}{ Model } & \multicolumn{2}{|c|}{$\begin{array}{l}\text { Unstandard- } \\
\text { ized Coeff. }\end{array}$} & \multirow{2}{*}{$\begin{array}{c}\begin{array}{c}\text { Standard- } \\
\text { ized Coeff. }\end{array} \\
\text { Beta }\end{array}$} & \multirow[t]{2}{*}{$t$} & \multirow[t]{2}{*}{ Sig. } & \multicolumn{3}{|c|}{ Correlations } & \multicolumn{2}{|c|}{$\begin{array}{c}\text { Collinearity } \\
\text { Statistics }\end{array}$} \\
\hline & & B & $\begin{array}{l}\text { Std. } \\
\text { Error }\end{array}$ & & & & $\begin{array}{l}\text { Zero- } \\
\text { order }\end{array}$ & Partial & Part & $\begin{array}{l}\text { Toler- } \\
\text { ance }\end{array}$ & VIF \\
\hline \multirow[t]{5}{*}{ HUN } & (Constant) & -.421 & .086 & & -4.927 & .000 & & & & & \\
\hline & ATT & .819 & .010 & .798 & 84.896 & .000 & .868 & .780 & .604 & .573 & 1.745 \\
\hline & SUB & -.032 & .014 & -.019 & -2.349 & .019 & .413 & -.034 & -.017 & .741 & 1.349 \\
\hline & LOC & .006 & .015 & .003 & .393 & .695 & .277 & .006 & .003 & .776 & 1.289 \\
\hline & SEF & .183 & .013 & .131 & 13.608 & .000 & .601 & .196 & .097 & .548 & 1.823 \\
\hline \multirow[t]{5}{*}{ POL } & (Constant) & -.516 & .082 & & -6.330 & .000 & & & & & \\
\hline & ATT & .852 & .011 & .729 & 75.326 & .000 & .806 & .708 & .575 & .622 & 1.608 \\
\hline & SUB & -.028 & .013 & -.019 & -2.243 & .025 & .310 & -.030 & -.017 & .814 & 1.228 \\
\hline & LOC & -.085 & .014 & -.053 & -5.988 & .000 & .316 & -.079 & -.046 & .744 & 1.343 \\
\hline & SEF & .250 & .013 & .184 & 18.658 & .000 & .568 & .241 & .143 & .599 & 1.668 \\
\hline \multirow[t]{5}{*}{ CZE } & (Constant) & .298 & .165 & & 1.799 & .072 & & & & & \\
\hline & ATT & .896 & .020 & .837 & 44.794 & .000 & .862 & .825 & .713 & .725 & 1.380 \\
\hline & SUB & -.029 & .029 & -.018 & -1.017 & .309 & .308 & -.033 & -.016 & .799 & 1.252 \\
\hline & LOC & -.211 & .029 & -.130 & -7.334 & .000 & .108 & -.232 & -.117 & .803 & 1.246 \\
\hline & SEF & .183 & .029 & .125 & 6.228 & .000 & .467 & .199 & .099 & .628 & 1.591 \\
\hline \multirow[t]{5}{*}{ SVK } & (Constant) & -.684 & .098 & & -7.018 & .000 & & & & & \\
\hline & ATT & .866 & .013 & .800 & 67.364 & .000 & .870 & .785 & .613 & .587 & 1.704 \\
\hline & SUB & -.028 & .016 & -.018 & -1.687 & .092 & .396 & -.032 & -.015 & .760 & 1.317 \\
\hline & LOC & .004 & .018 & .002 & .214 & .831 & .327 & .004 & .002 & .766 & 1.305 \\
\hline & SEF & .185 & .018 & .128 & 10.346 & .000 & .603 & .191 & .094 & .544 & 1.839 \\
\hline
\end{tabular}

Source: own calculation based on GUESSS 2016

The data in the tables above reveal that it is the attitudes that affect start-up intentions. The previous tests of the model also indicate the direct effects of attitudes on start-ups. (Autio et al. 2001; Krueger et al. 2000; Nishimura and Tristán 2011; Liñán and Chen 2009; Gubik, 2013). The more positive personal attitudes towards entrepreneurship individuals have, the more they can imagine themselves in the role of entrepreneurs.

As for the self-efficacy variable of the perceived behavioural control, the value of the standardized regression coefficient is a lot lower and the correlation is also positive in all Visegrad countries (the highest partial correlation coefficient can be found in the Polish sample). The more respondents feel that they possess the necessary knowledge and information for start-ups, the more willing they are to start their own businesses. 
As for the locus of control variable of the perceived behavioural control, a significant correlation was observed only in the Czech Republic and Poland. However, in the Polish sample the value of the partial correlation coefficient indicates that this variable has little explanatory power for explanations of variations in entrepreneurial start-up intentions. Thus, the relationship in the Polish sample cannot be justified.

In the sample of the Czech Republic, the locus of control exhibits significant correlation with start-up intentions, but the negative sign in front of the correlation contradicts the initial hypothesis. Additional tests with the Czech sample were carried out. Questions related to career aspirations were also analysed to test the effect of the locus of control on start-up intentions, and the obtained results also confirm the negative relationship. Behind this, there may be differences in value that determine whether people in a country consider a business or other professional career a desirable career path. Examining this is beyond the scope of this article, but again draws attention to the crucial role of soft factors.

Significance values were observed regarding the subjective norm in the Hungarian and Polish samples. However, beta values and partial correlation coefficients were extremely low in both samples, which also contradicted the initial hypothesis. A significant number of previous tests provided similar results (Autio et al. 2001; Krueger et al. 2000; Nishimura and Tristán 2011; Liñán and Chen, 2009; Gubik, 2013).

Although the relationship between subjective norm and entrepreneurial intention is not significant, the analysis of partial correlation coefficients justified that there is a positive significant relationship between subjective norms and attitudes in all countries under investigation. Subjective norms embody opinions, support and critical attitudes of the students' environment. Social acceptance of entrepreneurial thinking (if this casual direction is accepted) favourably affects entrepreneurial attitudes. Thus, norms affect entrepreneurial start-ups through attitudes and indirectly. The social acceptance of entrepreneurship was still low in former socialist countries. The analysis conducted by Szerb and Kocsis-Kisantal also confirmed this phenomenon (Szerb and Kocsis-Kisantal, 2008) and showed a negative picture in the Hungarian context. This also had an adverse effect on start-up visions, if the above correlations related to norms, attitudes and intentions were accepted.

Social norms also show a positive correlation with perceived behavioural control, but this relationship is not significant in all Visegrad countries. The correlation between selfefficacy and norms is significant and positive in all countries except Hungary. As for the relationship between these norms and the locus of control, a positive link between the variables can be detected only in the Czech Republic and Slovak Republic.

Self-efficacy and locus of control were positively correlated in all Visegrad countries. The possession of knowledge and information was related to the perceived control. Further analyses are needed to determine the direction of causation since it is not clear, whether students are more self-confident if they are more knowledgeable and have more information or whether the increase in self-efficacy results in a more favourable perception of knowledge. For other relationships, differences were observed among Visegrad countries, which need further analyses. Table 5 illustrates these relationships. 
Table 5: Partial correlation coefficients

\begin{tabular}{|l|r|r|r|r|}
\hline & HUN & \multicolumn{1}{c|}{ POL } & CZE & \multicolumn{1}{c|}{ SVK } \\
\hline INT - ATT & 0.780 & 0.708 & 0.825 & 0.785 \\
INT - SUB & -0.034 & -0.030 & -0.033 & -0.032 \\
INT - SEF & 0.196 & 0.241 & 0.199 & 0.191 \\
INT - LOC & 0.006 & -0.079 & -0.232 & 0.004 \\
ATT - SUB & 0.236 & 0.179 & 0.157 & 0.194 \\
ATT - SEF & 0.147 & 0.126 & 0.045 & 0.133 \\
ATT - LOC & 0.031 & 0.159 & 0.188 & 0.025 \\
SUB - SEF & 0.090 & 0.120 & 0.200 & 0.154 \\
SUB - LOC & 0.141 & 0.127 & 0.093 & 0.096 \\
SEF - LOC & 0.354 & 0.308 & 0.381 & 0.330 \\
\hline
\end{tabular}

Source: own calculation based on GUESSS 2016

After the partial relationships and the causation relationships between model variables had been analysed, linear regression model was extended and included gender, age, family business background and higher education institution (entrepreneurship education programs, entrepreneurial atmosphere at universities) variables. However, experimenting with these variables did not increase the explanatory power of the model.

The age variable did not correlate with analysed variables. The variance analysis showed weak and significant relationship between the gender variable and the entrepreneurial intention variable, but when the gender variable was included in the linear regression model as a dummy variable, the explanatory power of the model increased only by onetenth percentage points.

Similar results were obtained for family business background. The variance analysis showed a weak relationship between the family business background and the entrepreneurial intention variable. However, this variable did not perform well in the linear regression model.

Finally, the entrepreneurial atmosphere at universities and entrepreneurship education programs were in positive relationship with entrepreneurial intentions. However, when the model factors (attitudes, norms and control) were controlled, this relationship could not be detected. The analysis of partial correlation coefficients demonstrated that the variables measuring the influence of higher institutions were involved in the model indirectly, through a significant relationship with self-efficacy. The role of education, especially higher education, in shaping entrepreneurial visions is crucial.

Based on the reported findings, the factors contributing to the evaluation of possible solutions related to entrepreneurship education seem to be as follows: 
* Collect and systematise knowledge and information related to enterprises and making them accessible to students. This should be carried out in parallel and through multi channels. More specifically, the information should be available from adequate interfaces, the knowledge should be incorporated in the teaching material of courses and higher institutions should operate Entrepreneurship Centres. Knowledge, experience and the related control perception enhance entrepreneurial attitudes and also contribute to fostering entrepreneurial intentions.

* Creating an entrepreneurial environment demonstrates a commitment to entrepreneurial values, which should be integrated in the curriculum and appear in communication. All these actions may influence entrepreneurial intentions through self-efficacy.

* Present good examples so that students can gain vicarious experiences. According to Bandura (1995), telling students stories about students who are already successful entrepreneurs is very important. These role models influence the self-efficacy and results in developing a positive attitude towards entrepreneurship.

* Create, if possible, controlled environment so that students can gain personal experiences (Bandura (1995) terms them as mastery experiences) and realise how beneficial these experiences are for their personal development. In addition, instructors/mentors should provide a feedback on students' individual results. Also the strategies dealing with failures are very important.

* We need to give students deeper motivations. It should be made clear that entrepreneurial activity is not only about money and self-employment, but also a possible tool of self-realization The achievement of social goals and the opportunity to create social value can also be the main drivers of entrepreneurial activity.

The results show that there are differences in Visegrad countries regarding the model's implications, which may help identify and influence effective intervention areas.

\section{Conclusion}

his paper attempts to identify factors that influence students' entrepreneurial intentions. Factors of Ajzen's theory seem to provide adequate explanation of these intentions. Although Ajzen's theory of planned behaviour was not designed to model entrepreneurship, it helps understand the complexity of the decision to choose the entrepreneurial career and identifies key areas for effective intervention that would channel entrepreneurship in a favourable direction. The results of this research and drawn experiences are as follows:

* Attitudes considerably influence entrepreneurial intentions. Their development may be rather time consuming and require consistent and long-term intervention.

* Social norms, that is, behaviour of the environment (family, friends, etc.) shapes entrepreneurial attitudes. Alongside the positive support received from the society, which is difficult to influence and can be shaped very slowly, higher education may be the only relatively rapid developer of norms. 
* Self-efficacy related to entrepreneurship and knowledge of entrepreneurial processes also significantly affects entrepreneurial intentions. More self-confident students (higher locus of control) have higher self-efficacy. Thus, knowledge transfer and active experimentation and practice in different situations may promote entrepreneurial intentions. The significant relationship between higher education variables and self-efficacy also demonstrate this.

* Students' family business background and education also determine their entrepreneurial visions, but neither the age nor the gender that are frequently investigated in the literature can significantly increase the explanatory power of the model. Their affect may be perceived in different attitudes and different behavioural control.

Understanding the reasons that lie behind students' decisions to become entrepreneurs plays an important role in entrepreneurship promotion and help formulate policies that increase the rate of young people who intend to start their own businesses. It has been long experienced that more should be done in order to enhance students' start-up intentions than providing financial resources necessary for forming enterprises or reducing administrative burdens. The results of the study clearly demonstrate that any major shifts in start-up intentions (except for knowledge transfer) are likely to be very slowly and require a high degree of political commitment.

The experienced differences (entrepreneurial intentions and factors that shape intentions) among the Visegrad countries indicate that methods applied to promote entrepreneurship in the Visegrad countries should be tailored to the country's and students' needs and context. These can be more effective than the widely used generic solutions.

It is plausible that a number of limitations could have influenced the results obtained. First, the study focused only on students studying in tertiary education and their start-up intentions and did not sample entrepreneurial intentions of the whole youth population. Furthermore, the research method (questionnaire) failed to reveal a lot of hidden individual motives. Applying qualitative research methods (case studies and interviews) could have helped to ensure a better understanding of the topic.

\section{References}

Ajzen, I. (1991). The Theory of Planned Behavior Organizational. Behavior and Human Decision Processes, 50(2), 179-211.

Ajzen, I. (2006a). Constructing a Theory of Planned Behavior Questionnaire - Brief Description of the Theory of Planned Behavior. Retrieved November 15, 2017, from http://people.umass.edu/aizen/pdf/tpb.measurement.pdf.

Ajzen, I. (2006b). Behavioral Interventions Based on the Theory of Planned Behavior. Technical Report. January 2006. Retrieved November 15, 2017, from https://people.umass. edu/aizen/pdf/tpb.intervention.pdf.

Autio, E., Keeley, R. H., Klosfsten, M., Parker, G. C. and Hay, M. (2001). Entrepreneurial Intent among Students in Scandinavia and in the USA. Enterprise and Innovation Management Studies, 2(2), 145-160. 
Autio, E. and Wennberg, K. (2010). You think, therefore, I become: Social attitudes and the transition to entrepreneurship. Paper presented at DRUID Summer Conference 2010, Imperial College London Business School, 16-18 June 2010, London.

Autio, E. (2005). Report on High-Expectation Entrepreneurship. Global Entrepreneurship Monitor, London Business School - Babson College. Retrieved September 12, 2016, from http://new.gemconsortium.org/assets/uploads/-1313506401GEM_2005_High_Growth _Report.pdf.

Bandura, A. (1977). Social Learning Theory. Englewood Cliffs, New Jersey: Prentice-Hall. Bandura, A. (1989). Social cognitive theory. In: R. Vasta (Ed.) Annals of Child Development. Vol. 6. Six theories of child development (pp. 1-60). Greenwich, CT: JAI Press. Bandura, A. (1995). Self-Efficacy in Changing Societies. Cambridge University Press. Beauchamp, M. and Skala, A. (2017). Visegrad Startup Report 2016/2017. Visegrad Fund Retrieved March 17, 2018, from https://s3.eu-central-1.amazonaws.com/uploads.mangoweb.org/sharedprod/aspeninstitutece.org/uploads/2017/06/Visegrad-Startup-Report-5.pdf. Carree, M. A. and Thurik, A. R. (2010). The Impact of entrepreneurship on Economic Growth. In: Zoltan Acs and David Audretsch (eds.) International Handbook of Entrepreneurship Research, 2nd edition. Springer New York: Springer, 557-594.

EC (2008). Entrepreneurship in Higher Education. Especially within Non-business Studies Final Report of the Expert Group European Commission. Retrieved October 20, 2016, from http://ec.europa.eu/enterprise/entrepreneurship/support_measures/-training_education/entr_highed.pdf.

EC (2013). Entrepreneurship 2020 Action Plan. Retrieved October 20, 2016, from http://ec.europa.eu/growth/smes/promoting-entrepreneurship/action-plan/.

Egerová, D., Eger, L. and Micik, M. (2017). Does entrepreneurship education matter? Business students' perspectives. Tertiary Education and Management, 23(1), 1-15.

Engle, R. L., Dimitriadi, N., Gavidia, J. V., Schlaegel, Ch., Delanoe, S., Alvarado, I., He, X., Buame, S. and Wolff, B. (2010). Entrepreneurial Intent: A Twelve country Evaluation of Ajzen's Model of Planned Behavior. International Journal of Entrepreneurial Behavior and Research, 16(1), 35-57.

Eurobarometer (2011). Youth on the move. Analytical report. Flash EB No 319b. Retrieved September, 25, 2018, from http://ec.europa.eu/commfrontoffice/-publicopinion/flash/f1_319b_en.pdf.

Eurofound (2015). Youth entrepreneurship in Europe: Values, attitudes, policies. Publications Office of the European Union, Luxembourg. Retrieved September, 25, 2018, from https://www.eurofound.europa.eu/sites/default/files/ef_publication/-field_ef_document/ ef1507en.pdf.

EYE (2015). Erasmus for Young Entrepeneurs. Retrieved September 25, 2018, from http://www.erasmus-entrepreneurs.eu/upload/Programme\%20Guide\%20EN\%20-May\%202015.pdf.

Gauthier, J. F., Stangler, D., Penzel, M., Morelix, A. and Ortmans, J. (2018). Global Startup Ecosystem Report 2018. Succeeding in the New Era of Technology. Startup Genome and Global Entrepreneurship Network (GEN). Retrieved February 12, 2019, from https://startupgenome.com/reports/2018/GSER-2018-v1.1.pdf. 
Gubik, S. Andrea (2013). A magyar hallgatók vállalkozásindító szándékát befolyásoló tényezők modellje - Ajzen tervezett magatartás elméletének kiterjesztése (Model of the Hungarian students' business start-up intention influencing factors - Extending of Ajzen's Theory of Planned Behavior). Vezetéstudomány, 44(7-8.), 5-17.

Gubik, S. Andrea (2016): Magyar egyetemi hallgatók karrierterveinek alakulása és kihatásuk a jövoóbeli vállalkozói hajlandóságra (The development of career plans of Hungarian university students and their impact on future entrepreneurial intention). In Tóth Attiláné and S. Gubik Andrea (eds.) Magyarország 2025-ben és kitekintés 2050-re: Tanulmánykötet Nováky Erzsébet 70. születésnapjára. Arisztotelész Kiadó, 91-102.

Gubik, S. A., Farkas, Sz. and Kása, R. (2018). A tervezett magatartás elméletének alkalmazása a vállalkozói hajlandóság alakulásának magyarázatára (Applying the theory of planned behaviour to explaining the evolution of entrepreneurship). Közgazdasági Szemle, 65(1), 74-101.

Holienka, M., Gál, P. and Kovačičová, Z. (2017). Drivers of Student Entrepreneurship in Visegrad Four Countries: GUESSS Evidence. Central European Business Review, 6(02), 54-63, DOI: 10.18267/j.cebr.180.

Holienka, M., Pilková, A. and Jančovičová, Z. (2016). Youth Entrepreneurship in Visegrad Countries. Entrepreneurial Business and Economics Review, 4(4), 105-121. DOI: http:// dx.doi.org/10.15678/EBER.2016.040407.

Hope, K. (ed.) (2016). Annual Report on European SMEs 2015/2016. SME Recovery Continues. European Commission. DOI 10.2873/76227.

Hunady, J., Orviska, M. and Pisar, P. (2018). The Effect of Higher Education on Entrepreneurial Activities and Starting Up Successful Businesses. Inzinerine EkonomikaEngineering Economics, 29(2), 226-235.

Imreh-Tóth Mónika (2015). Az egyetemi vállalkozásoktatás lehetséges szerepe a vállalkozóvá válás elósegítésében (The potential role of the entrepreneurship education of universities in the promotion of entrepreneurship). Szeged: JATEPress, 2015. 150 p.

Kautonen, T., van Gelderen, M. and Fink, M. (2015). Robustness of the Theory of Planned Behavior in Predicting Entrepreneurial Intentions and Actions. Entrepreneurship Theory and Practice, 39(3), 655-674.

Ketskeméty, L. and Izsó, L. (2005). Bevezetés az SPSS programrendszerbe. Módszertani útmutató és feladatgyújtemény statisztikai elemzésekhez (Introduction to the SPSS Program Package). ELTE Eötvös Kiadó, Budapest.

Kolstad, I. and Wiig, A. (2015). Education and entrepreneurial success. Small Business Economics, 44(4), 783-796.

Kolvereid, L. (1996). Prediction of Employment Status Choice Intentions. Entrepreneurs. Entrepreneurship: Theory and Practice, 21(1), 47-58.

Kovács, P. (2008). A multikollinearitás vizsgálata lineáris regressziós modellekben (Analysis of multicollinearity in linear regression models). Statisztikai Szemle, 86(1), 38-67.

Krueger, N., Reilly, M. D. and Carsrud, A. L. (2000). Competing Models of Entrepreneurial Intentions. Journal of Business Venturing, 15(5-6.), 411-432. 
Liñán, F. and Chen, Y-W. (2009). Development and Cross-Cultural Application of a Specific Instrument to Measure Entrepreneurial Intentions. Entrepreneurship: Theory and Practice, 33(3), 593-617.

Ling, H. and Venesaar, U. (2015). Enhancing Entrepreneurship Education in Engineering Students to Increase Their Metacognitive Abilities: Analysis of Student Self-Assessments. Inzinerine Ekonomika-Engineering Economics, 26(3), 333-342.

Lüthje, C. and Franke, N. (2002). Fostering Entrepreneurship through University Education and Training: Lessons from Massachusetts Institute of Technology. European Academy of Management, 2nd Annual Conference on Innovative Research in Management, 2002. May 9-11., Stockholm. Retrieved June 6, 2017, from http://citeseerx.ist.psu.edu/viewdoc/download?doi=10.1.1.203.2530\&rep=rep1\&type=pdf.

Maresch, D., Harms, R., Kailer, N. and Wimmer-Wurm, B. (2016). The impact of entrepreneurship education on the entrepreneurial intention of students in science and engineering versus business studies university programs. Technological Forecasting and Social Change, 104(3), 172-179.

Meager, N., Bates, P. and Cowling, M. (2003). An evaluation of business start up support for young people. National Institute Economic Review, 186(1), 59-72.

Nishimura, J. S. and Tristán, O. M. (2011). Using the Theory of Planned Behavior to Predict Nascent Entrepreneurship. Academia, Revista Latinoamericana de Administración, 46, 55-71. Retrieved November, 24, 2013 from http://revistaacademia.cladea.org.

Nowiński, W., Haddoud, M.Y., Lančarič, D., Egerová, D. and Czeglédi, Cs. (2017). The impact of entrepreneurship education, entrepreneurial self-efficacy and gender on entrepreneurial intentions of university students in the Visegrad countries. Studies in Higher Education, 44(2), 1-19.

Ozaralli, N. and Rivenburgh, N. K. (2016). Entrepreneurial Intention: Antecedents to Entrepreneurial Behavior in the U.S.A. and Turkey. Journal of Global Entrepreneurship Research, 6(3), 2-32.

Plant, R. and Ren, J. (2010). A Comparative Study of Motivation and Entrepreneurial Intentionality: Chinese and American Perspectives. Journal of Developmental Entrepreneurship, 15(2), 187-204.

Schrör, H. (2006). The profile of the successful entrepreneur. Results of the survey 'Factors of Business Success'. Statistics in focus 29/2006, Eurostat.

Shane, S., Kolvereid, L. and Westhead, P. (1991). An Exploratory Examination of the Reasons Leading to New Firm Formation Across Country and Gender. Journal of Business Venturing, 6(6), 431-446.

Shapero, A. and Sokol, L. (1982): The social dimensions of entrepreneurship. In Kent, C.A., Sexton, D.L. and Vesper, K.H. (eds.) Encyclopedia of entrepreneurship. PrenticeHall, Inc., New Jersey: Englewood Cliffs. 72-90.

Szerb, L. and Kocsis-Kisantal, O. (2008). Vállalkozói kultúra Magyarországon két napilap tükrében (Entrepreneruship culture in Hungary in the face of two dailies). Közgazdasági Szemle, 55(3), 243-261.

Szerb, L. and Lukovszki, L. (2013). Magyar egyetemi hallgatók vállalkozási attitúdjei és az attitúdöket befolyásoló tényező́k elemzése a GUESSS-felmérés adatai alapján - Kik is 
akarnak ténylegesen vállalkozni? (Entrepreneurial attitudes of the Hungarian students and the analysis of the factors influencing attitudes based on the datas of GUESSS survey Who want to undertake really?) Vezetéstudomány, 44(7-8.), 30-40.

Szerb, L. and Márkus, G. (2007). A felsőoktatási környezet hatása a vállalkozói életpálya választására. Nemzetközi összehasonlító elemzés, 2006. (The effect of higher-education environment on choice of entrepreneurial career. An international comparative analysis in 2006). Közgazdasági Szemle, 54(3), 248-273.

Szerb, L. and Trumbull, W. N. (2015). Entrepreneurship and entrepreneurial ecosystem in the V4 countries: The Global Entrepreneurship Index perspective. In Proceedings of the 5th International Conference on Management 2015. Management, leadership and strategy for SMEs' competitiveness. Szent István University Publishing House, Gödöllő, 2-7. ISBN 978-963-269-492-4.

Szilágyi, R. and Varga, B. (2011). Kvantitatív információképzési technikák. (Quantitative Information Forming Methods). Nemzeti Tankönyvkiadó.

Szirmai, P. and Csapó, K. (2006). Gyakorlati vállalkozásoktatás - Diákvállalkozások támogatása a Budapesti Corvinus Egyetemen (Entrepreneurship education - promoting of students' enterprises at the University of Corvinus). Új pedagógiai szemle, 56(4), 72-83. Thomas, A. S. and Mueller, S. L. (2000). A Case for Comparative Entrepreneurship: Assessing the Relevance of Culture. Journal of International Business Studies, 31(2), 287-301.

Thurik, R. and Dejardin, M. (2012). Entrepreneurship and Culture. In Marco van Gelderen and Enno Masurel (eds). Entrepreneurship in Context. Routledge, Routledge Studies in Entrepreneurship. 175-186.

von Graevenitz, G., Harhoff, D. and Weber, R. (2010). The effects of entrepreneurship education. Journal of Economic Behavior and Organization, 76(1), 90-112.

Wach, K. and Wojciechowski, L. (2016). Entrepreneurial Intentions of Students in Poland in the view of Ajzen's Theory of Planned Behaviour. Entrepreneurial Business and Economics Review, 4(1), 83-94.

Zellweger, T., Sieger, P. and Halter, F. (2011). Should I Stay or Should I Go? Career Choice Intentions of Students with Family Business Background. Journal of Business Venturing, 26(5), 521-536.

Zhao, X., Li, H. and Rauch, A. (2012). Cross-country Differences in Entrepreneurial Activity: The Role of Cultural Practice and National Wealth. Frontiers of Business Research in China, 6(4), 447-474. 